\begin{tabular}{|c|c|c|c|}
\hline $\begin{array}{l}\text { Case Reports in } \\
\text { Dermatoloy }\end{array}$ & \begin{tabular}{|l|} 
Case Rep Dermatol 2010;2:201-206 \\
DOI: $\underline{10.1159 / 000323467}$
\end{tabular} & $\begin{array}{l}\text { Published online: } \\
\text { December 22, } 2010\end{array}$ & $\begin{array}{l}\text { | } 2010 \text { S. Karger AG, Basel } \\
\text { ISSN 1662-6567 } \\
\text { www.karger.com/cde }\end{array}$ \\
\hline
\end{tabular}

\title{
Sequential Acral Lentiginous Melanomas of the Foot
}

\author{
Jiro Uehara ${ }^{a}$ Yasuhiro Ito $^{a}$ Ichiro Takahashi ${ }^{a}$ \\ Masaru Honma ${ }^{a}$ Akemi Ishida-Yamamoto ${ }^{a}$ \\ Shinobu Matsuo ${ }^{b}$ Hajime lizuka ${ }^{a}$ \\ ${ }^{a}$ Department of Dermatology, Asahikawa Medical College, and ${ }^{b}$ Matsuo \\ Dermatology Clinic, Asahikawa, Japan
}

\section{Key Words}

Acral lentiginous melanoma $\cdot$ Cyclin $D_{1} \cdot$ Field cell model · Melanoma spread · Primary melanoma $\cdot$ Surgical margins

\begin{abstract}
A 64-year-old Japanese woman had a lightly brown-blackish pigmented macule $(1.2 \mathrm{~cm}$ in diameter) on the left sole of her foot. She received surgical excision following a diagnosis of acral lentiginous melanoma (ALM), which was confirmed histopathologically. One month after the operation, a second melanoma lesion was noticed adjacent to the grafted site. Histopathologically, the two lesions had no continuity, but HMB- 45 and cyclin $D_{1}$ double-positive cells were detected not only on aggregates of atypical melanocytes but also on single cells near the cutting edge of the first lesion. The unique occurrence of a sequential lesion of a primary melanoma might be caused by stimulated subclinical field cells during the wound healing process following the initial operation. This case warrants further investigation to establish the appropriate surgical margin of ALM lesions.
\end{abstract}

\section{Introduction}

Acral lentiginous melanoma (ALM) is the most common clinical type of melanoma in Orientals, accounting for $47 \%$ of all Japanese melanomas and for $27 \%$ of those located on the sole of the foot [1]. Local recurrences may be observed adjacent to the primary site following resection. We report a case of ALM, in which a second ALM adjacent to the primary site developed 1 month after resection, which was not recognized at the time of the initial operation. 


\begin{tabular}{c|l|l|l} 
Case Reports in & $\begin{array}{l}\text { Case Rep Dermatol 2010;2:201-206 } \\
\text { DOI: } 10.1159 / 000323467\end{array}$ & $\begin{array}{l}\text { Published online: } \\
\text { December 22, 2010 }\end{array}$ & $\begin{array}{l}\text { ISSN 1662-6567 } \\
\text { www.karger.com/cde }\end{array}$ \\
\hline
\end{tabular}

\section{Case Report}

A 64-year-old Japanese woman noticed a lightly brown-blackish pigmented macule (diameter: 1.2 $\mathrm{cm}$ ) on the sole of her left foot (fig. 1). Clinical examination revealed neither inguinal nor popliteal lymph node swelling. Dermoscopy disclosed a parallel ridge pattern with partial depigmented area (fig. 2). Following the clinical diagnosis of ALM, tumor resection was performed with a $1.0-\mathrm{cm}$ margin including deep fat tissue. Histological diagnosis was ALM in situ (fig. 3). One month after the first operation, however, another blackish macule was found $5 \mathrm{~mm}$ adjacent to the grafted margin (fig. 4a). The lesion rapidly enlarged to a 1.2 -cm blackish variegated-colored macule (fig. 4b); dermoscopically, a multi-component pattern with parallel ridges, irregular dots and focal hypopigmentation was noted (fig. 5). Two months after the first operation, local excision for ALM was again performed with a 1.5-cm margin. Histopathology disclosed atypical melanocytes with papillary dermal invasion (fig. 6). The pathological staging of the second lesion was $\mathrm{pT}_{1 \mathrm{a}} \mathrm{N}_{0} \mathrm{M}_{0}$ (stage IA according to the UICC 2002 criteria Breslow tumor thickness $0.5 \mathrm{~mm}$ and Clark level II). No recurrences or distant metastases have been detected 16 months after the second operation. HMB-45 and cyclin $\mathrm{D}_{1}$ double immunofluorescence staining of the first lesion disclosed double-positive cells not only on aggregates of atypical melanocytes but also on single cells near the cutting edge (fig. 7), indicating a proliferative potential of these cells. Double-positive cells were also detected in the second melanoma lesion (data not shown).

\section{Discussion}

We regard this case as a rare manifestation of sequential spread of primary melanomas. Initially, no clinically discernible lesion was noted at the site of the second melanoma (fig. 1). Retrospective re-examination could not disclose any pigmented lesion at the time of the first operation. Careful histopathological examination also failed to reveal any continuity between the two lesions.

The unique presentation of the development of the second melanoma in such a short period might be explained by the field cell model proposed by Bastian [2]. According to his model, field cells show genomic alterations despite the absence of histological or proliferative abnormalities. He reported cyclin $\mathrm{D}_{1}$ gene amplification in ALM lesions by fluorescent in situ hybridization (FISH). Our HMB- 45 and cyclin $\mathrm{D}_{1}$ double immunofluorescence analysis is consistent with his hypothesis that the quiescent field cells might have been activated by various growth factors of the graft site during wound healing, leading to local ALM recurrence. Wound fluid contains various growth factors, e.g. epidermal growth factor, platelet-derived growth factor, vascular endothelial growth factor, fibroblast growth factor and transforming growth factor- $\beta[3,4]$. North et al. [5] reported that $84 \%$ of acral melanomas contain FISH-detectable field cells, and in 5 of 19 cases field cells were detected at the surgical margin. However, clinically local recurrence was not observed in their patients followed up for 12-94 months (mean 51 months).

The surgical margin of melanoma is a matter of debate. To date, acral lesions have scarcely been studied in randomized controlled studies. The Japanese guidelines for cutaneous melanomas recommend a surgical margin of $0.5 \mathrm{~cm}$ for in situ lesions, $1.0 \mathrm{~cm}$ for melanomas $<2 \mathrm{~mm}$ (Breslow thickness) and $2.0 \mathrm{~cm}$ for melanomas $\geq 2 \mathrm{~mm}$ (Breslow thickness). Due to the lack of a correlation between field cell spread and tumor depth or size [5], evidence for the appropriate surgical margin of ALM is still inconclusive. A possible effect of complete resection (including field cells) on overall survival or recurrence-free survival remains to be determined. However, our case, albeit rare, suggests that further studies in this context may help to establish the appropriate surgical margin of ALM lesions. 


\begin{tabular}{c|l|l|l}
$\begin{array}{c}\text { Case Reports in } \\
\text { Demlintoloyy }\end{array}$ & $\begin{array}{l}\text { Case Rep Dermatol 2010;2:201-206 } \\
\text { DOI: } 10.1159 / 000323467\end{array}$ & $\begin{array}{l}\text { Published online: } \\
\text { December 22, 2010 }\end{array}$ & $\begin{array}{l}\text { O 2010 S. Karger AG, Basel } \\
\text { ISSN 1662-6567 } \\
\text { www.karger.com/cde }\end{array}$ \\
\hline
\end{tabular}

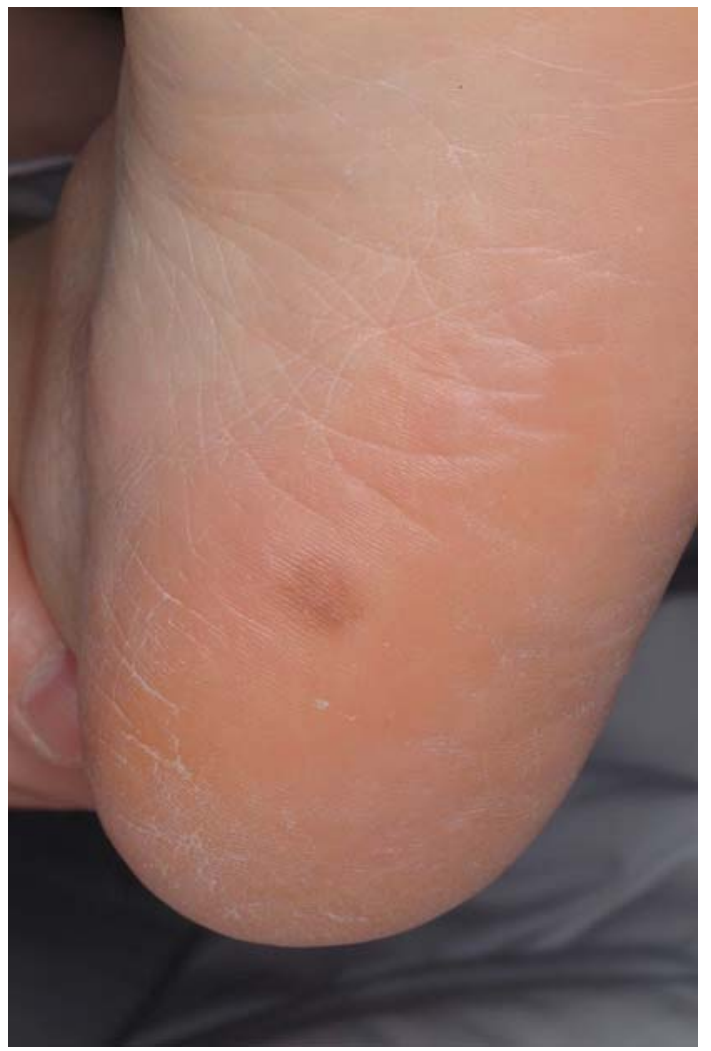

Fig. 1. Clinical appearance of the first lesion. A 1.0-cm brownish macule can be seen. Note: no second lesion is discernible on the lateral side.

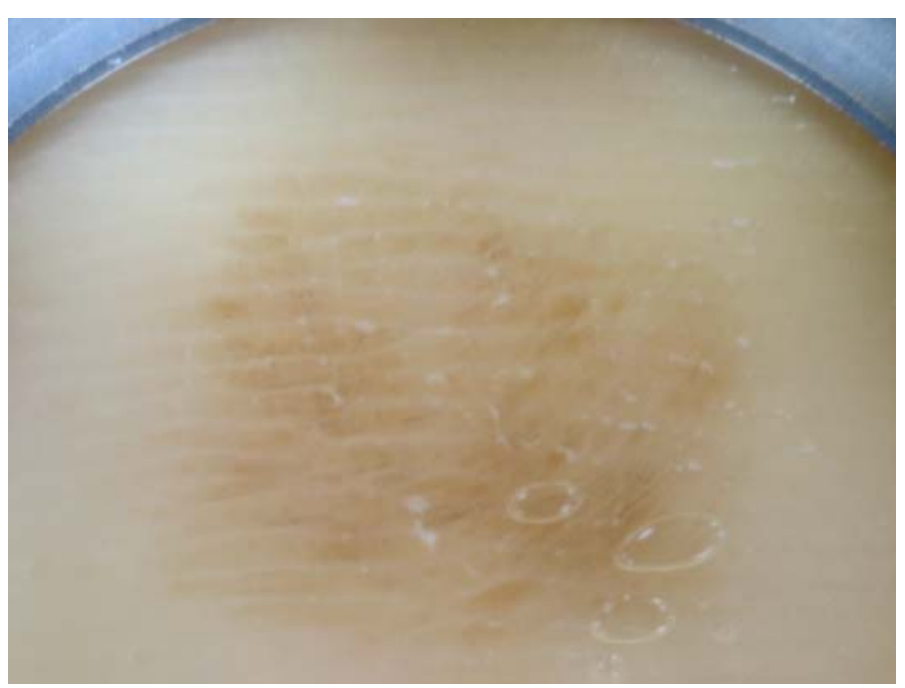

Fig. 2. Dermoscopy of the first lesion shows a parallel ridge pattern and focal hypopigmentation. 


\begin{tabular}{l|l|l|l}
$\begin{array}{c}\text { Case Reports in } \\
\text { Dermatology }\end{array}$ & $\begin{array}{l}\text { Case Rep Dermatol 2010;2:201-206 } \\
\text { DOI: } 10.1159 / 000323467\end{array}$ & $\begin{array}{l}\text { Published online: } \\
\text { December 22, 2010 }\end{array}$ & $\begin{array}{l}\text { I 2010 S. Karger AG, Basel } \\
\text { ISSN 1662-6567 } \\
\text { www.karger.com/cde }\end{array}$ \\
\hline
\end{tabular}

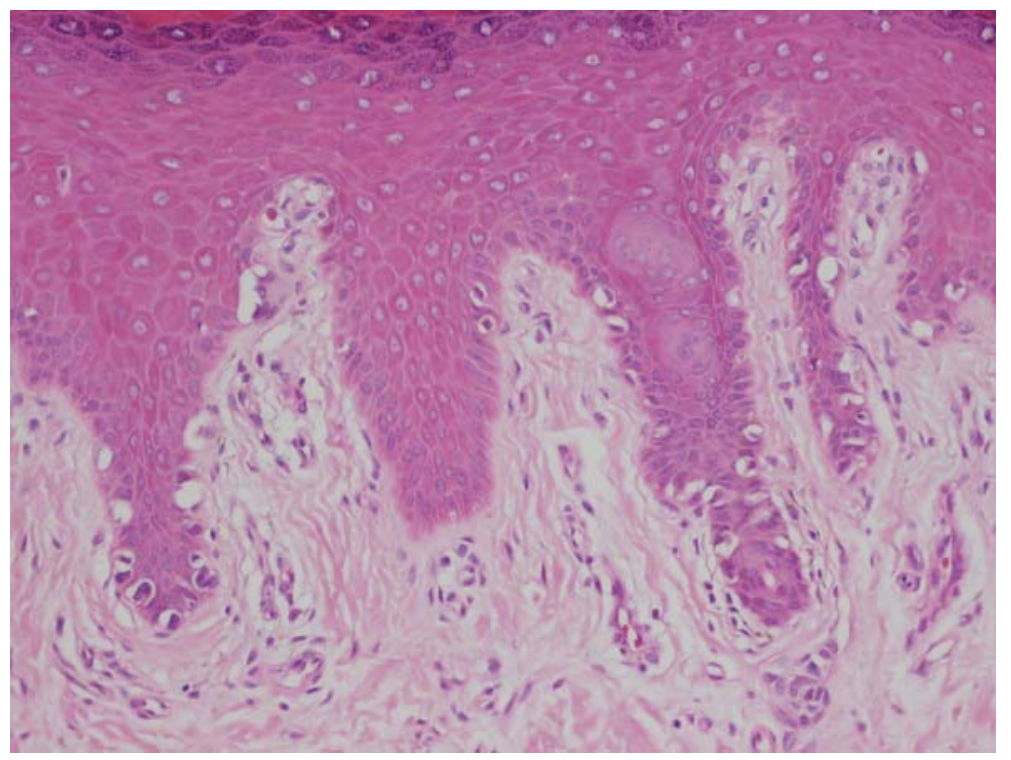

Fig. 3. Histopathology of the first lesion. Atypical melanocytes on the basal layer led to the diagnosis of ALM. No dermal invasion was detected.
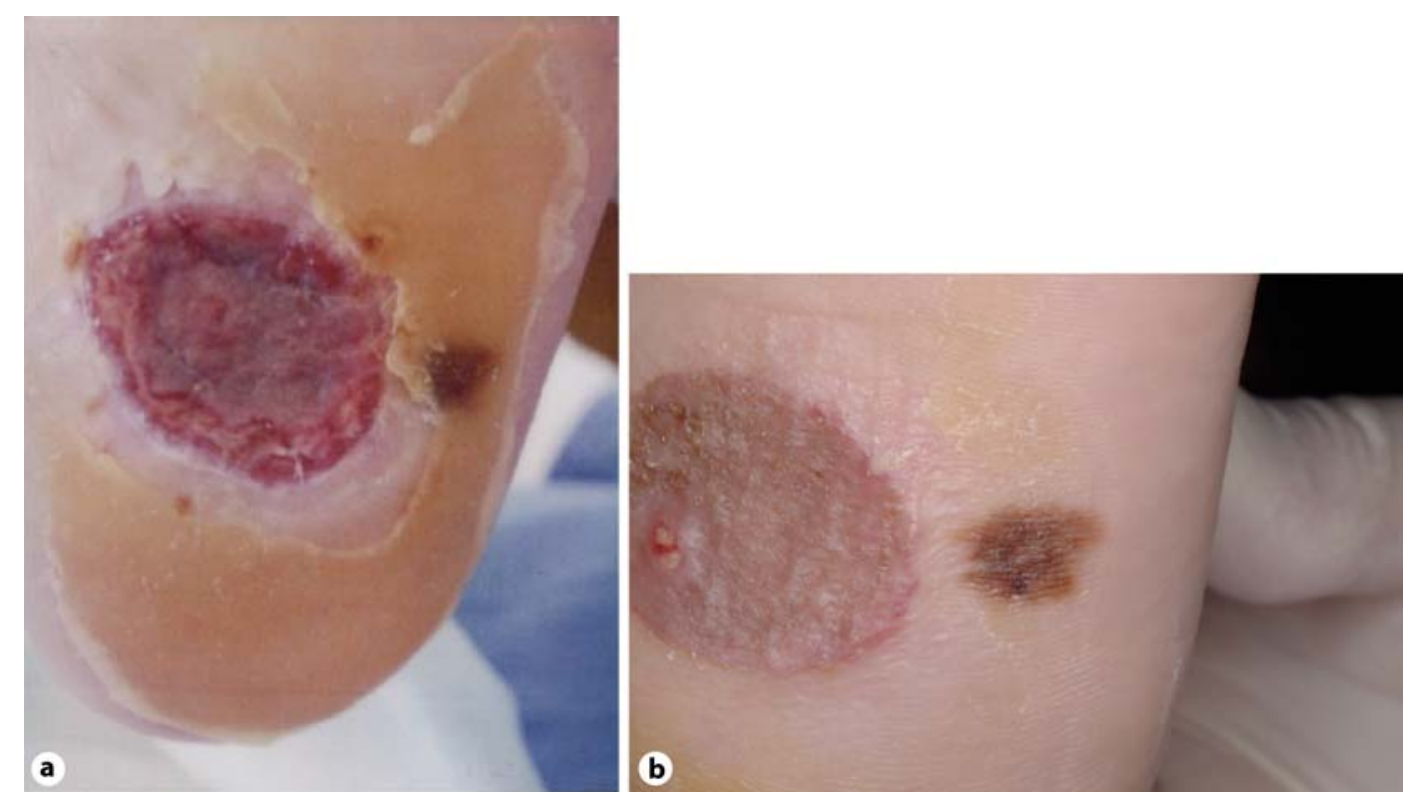

Fig. 4. Pigmented macule located $5 \mathrm{~mm}$ from the postgrafted scar. a Clinical appearance of the second lesion. A blackish macule was observed beside the first grafted site (on postoperative day 34). b Two months after the first operation, a $1.2-\mathrm{cm}$, ill-defined, irregularly shaped, blackish macule with color variegation was observed. 


\begin{tabular}{c|l|l|l}
$\begin{array}{c}\text { Case Reports in } \\
\text { Demlintoloyy }\end{array}$ & $\begin{array}{l}\text { Case Rep Dermatol 2010;2:201-206 } \\
\text { DOI: } 10.1159 / 000323467\end{array}$ & $\begin{array}{l}\text { Published online: } \\
\text { December 22, 2010 }\end{array}$ & $\begin{array}{l}\text { O 2010 S. Karger AG, Basel } \\
\text { ISSN 1662-6567 } \\
\text { www.karger.com/cde }\end{array}$ \\
\hline
\end{tabular}

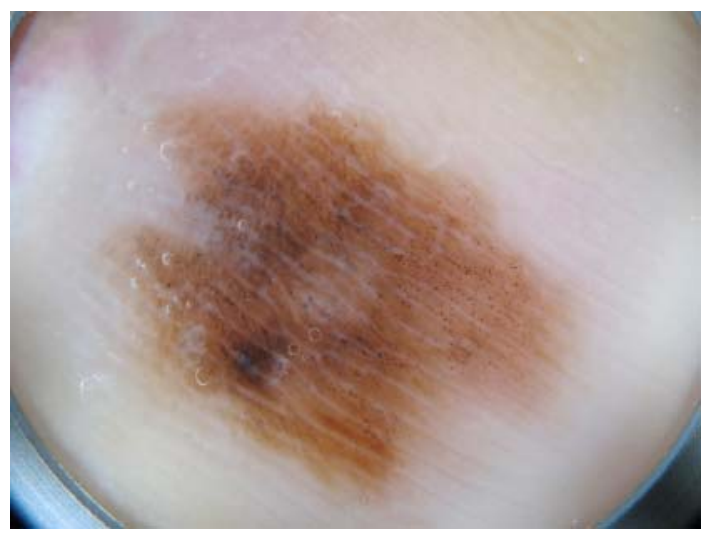

Fig. 5. Dermoscopy of the second lesion shows multiple components made of a parallel ridge pattern,with irregular distribution of small melanin dots and a focal hypopigmented component.

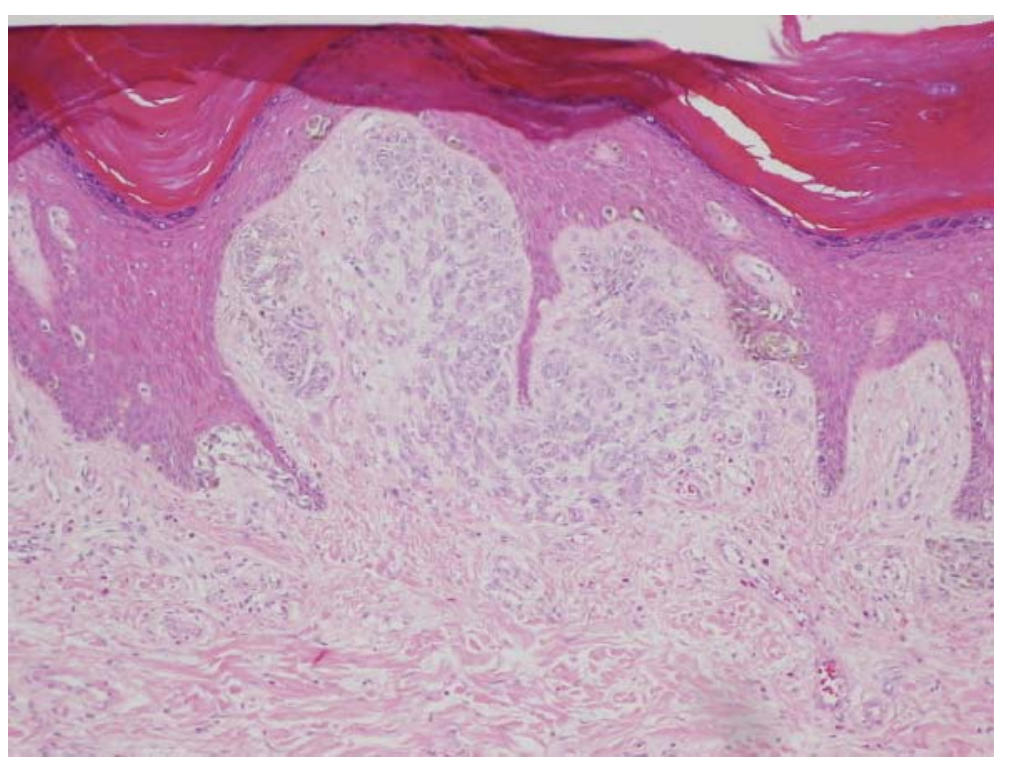

Fig. 6. Histopathology of the second lesion. Atypical epidermal melanocytes are observed with papillary dermal invasion. 


\begin{tabular}{r|l|l|l}
$\begin{array}{c}\text { Case Reports in } \\
\text { Dermatology }\end{array}$ & $\begin{array}{l}\text { Case Rep Dermatol 2010;2:201-206 } \\
\text { DOI: } 10.1159 / 000323467\end{array}$ & $\begin{array}{l}\text { Published online: } \\
\text { December 22, 2010 }\end{array}$ & $\begin{array}{l}\text { I 2010 S. Karger AG, Basel } \\
\text { ISSN 1662-6567 } \\
\text { www.karger.com/cde }\end{array}$ \\
\hline
\end{tabular}
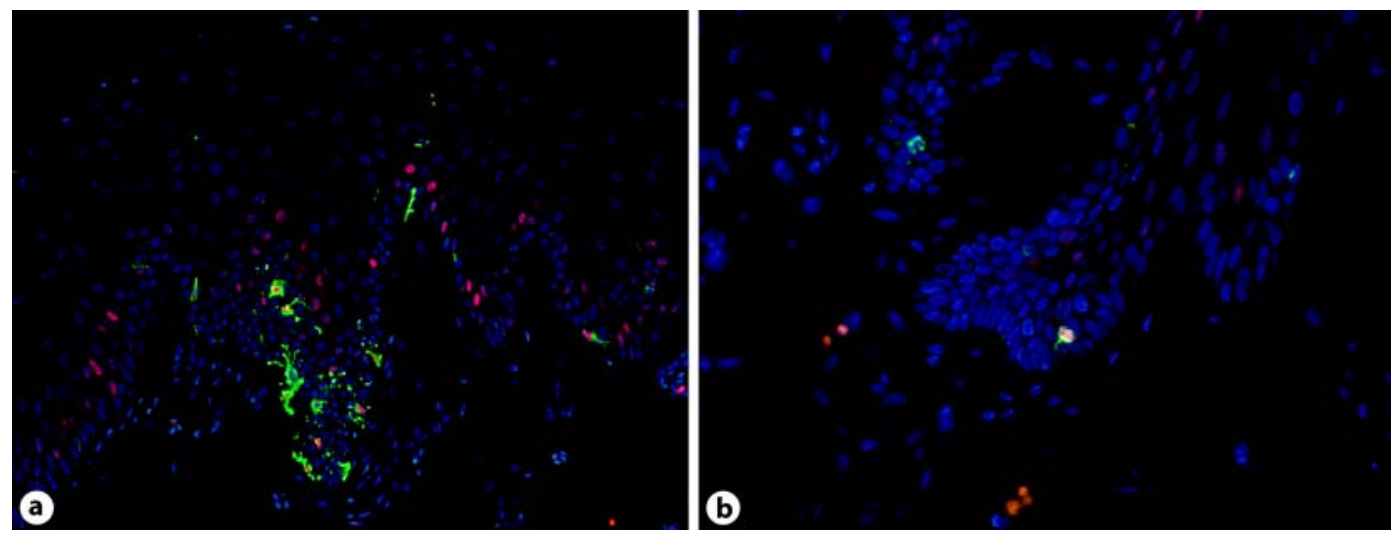

Fig. 7. Cytoplasmic HMB-45 (green) and nuclear cyclin $\mathrm{D}_{1}$ (red) double immunofluorescence staining. The aggregated melanocytes at the center of the first lesion (a) show double-positive staining. The single cell near the cutting edge (b) also shows double-positive staining.

\section{References}

1 Ishihara K, Saida T, Otsuka F, et al: Statistical profiles of malignant melanoma and other skin cancers in Japan: 2007 update. Int J Clin Oncol 2008;13:33-41.

2 Bastian BC: Understanding the progression of melanocytic neoplasia using genomic analysis: from fields to cancer. Oncogene 2003;22:3081-3086.

-3 Barrientos S, Stojadinovic O, Golinko MS, et al: Growth factors and cytokines in wound healing. Wound Repair Regen 2008;16:585-601.

4 Lazar-Molnar E, Hegyesi H, Toth S, et al: Autocrine and paracrine regulation by cytokines and growth factors in melanoma. Cytokine 2000;12:547-554.

5 North JP, Kageshita T, Pinkel D, et al: Distribution and significance of occult intraepidermal tumor cells surrounding primary melanoma. J Invest Dermatol 2008;128:2024-2030. 